Department of Global Public Health and Primary Care, University of Bergen, Norway

2 Graduate School of Public Policy, Nazarbayev University, Kazakhstan and Institute of Policy Studies, Lee Kuan Yew School of Public Policy, National University of Singapore, Singapore

3 Georgetown University - Qatar, Qatar

4 FAME Laboratory, Department of Physical Education and Sport Science, University of Thessaly, Greece

5 The Migrant Health Research Group Institute for Infection and Immunity, St George's, University of London, UK

Correspondence to: $\mathrm{K} H$ Onarheim kristine.onarheim@uib.no Cite this as: BMJ 2021;374:n1591 http://dx.doi.org/10.1136/bmj.n1591

Published: 5 August 2021

MIGRANT HEALTH

\title{
Health and social needs of migrant construction workers for big sporting events
}

\section{Governments, international sports bodies, and industry must take responsibility for barriers to health experienced by migrant workers involved in events such as the Olympic Games and FIFA World Cup, argue Kristine Husøy Onarheim and colleagues}

Kristine Husøy Onarheim, ${ }^{1}$ Kai Hong Phua, ${ }^{2}$ Zahra R Babar, ${ }^{3}$ Andreas D Flouris, ${ }^{4}$ Sally Hargreaves ${ }^{5}$

Migrant construction workers, a subgroup of the world's 164 million international labour migrants-the largest migrant group globally-leave their homes and families for employment opportunities in high income countries. ${ }^{1}$ Temporary jobs in construction industries meet demands in host countries and provide countries sending migrants and low skilled labourers with income, contributing to billions in remittances from high income countries each year. ${ }^{2}$

Big sporting events, such as the Summer Olympic Games 2020 held this year in Japan and the Fédération Internationale de Football Association (FIFA) World Cup 2022 in Qatar, entail intensive building of new stadiums and other facilities and are reliant on construction workers from low and middle income countries.

These sporting events provide platforms to showcase the host country and may bring short and long term interest from participating economies and industries. After intense lobbying to win the bid to host such events, the timeframe to build sporting arenas, as well as airports, hotels, and other infrastructure, is often short-around 10 years.

Civil society and businesses have brought attention to controversies around human rights violations and the sustainability of big sporting events. ${ }^{34}$ Although the health risks of mass gatherings are considered a public health priority, ${ }^{5}$ the health vulnerabilities of low skilled labour migrants concerned in constructing and maintaining venues before and during such events has received little attention. ${ }^{6}$

Building on our article examining the evidence base, ${ }^{6}$ this article provides recommendations for policy makers in government, international sports bodies, and the construction industry to promote health and access to health systems among migrant construction workers in upcoming big sporting events.

\section{Labour migrants' health}

A subgroup of labour migrants, migrant construction workers are generally young and relatively healthy before departure, but on arrival in the host country they may face unique health risks, vulnerabilities, and barriers to healthcare that may impact detrimentally on their health and wellbeing..$^{-9}$ Migration itself may expose migrants to health hazards. ${ }^{9}$ Social, economic, occupational, and structural determinants affect the health of migrants. ${ }^{10} 11$ International labour migrants are at considerable risk of work related ill health, including psychiatric and physical morbidities, workplace accidents, and injuries. ${ }^{12}$ A meta-analysis found that $47 \%$ and $22 \%$ of labour migrants globally experienced occupational morbidity and workplace injury or incident, respectively. ${ }^{12}$ A study of Nepali labour migrants returning from the Gulf and Malaysia concluded that non-compliance with labour agreements, abuse and exploitation by supervisors, lack of privacy, and crowded accommodation made them vulnerable to mental health conditions. ${ }^{13}$

Health problems are rooted in the financial, familial, living, and working conditions related to being a temporary labour migrant. ${ }^{1113}$ Aside from the health of labour migrants themselves, research has shown that the children they leave behind are at risk of depression, suicidal ideation, and anxiety. ${ }^{14}$

The temporariness and high pressure of work related to big sporting events may put migrant construction workers in social and working situations with unique risks. With short deadlines, they work irregular and long hours and during hot seasons, and they live in substandard and crowded housing, as documented in construction projects in the Olympics in Beijing and the planned FIFA World Cup in Qatar. ${ }^{15} 16$ Ethnographic, language, and psychosocial challenges also affect the health and social conditions of migrant construction workers concerned in big sporting events. $^{17-19}$

The covid-19 pandemic has shone a spotlight on global inequities facing migrant populations, with major health and social effects on migrants. Emerging evidence suggests that migrant populations, including labour migrants, in high income countries may have been disproportionately represented in covid-19 cases, admissions to hospital, and deaths. ${ }^{20} 21$ Labour migrants in many countries were largely excluded from national covid-19 responses, experiencing enforced lockdowns for often lengthy periods in crowded accommodation with poor surveillance. They had few opportunities for basic preventive hygiene and social distancing measures at home and at work (box 1). This has led to calls for them to be included in the covid-19 vaccine roll-out and prioritised as a group because of their risk factors. ${ }^{22} 26-28$ Lessons about the marginalisation of low skilled labour migrants are relevant beyond the 
covid-19 pandemic and for several sectors, with greater focus needed on safety, occupational hazards, and living conditions in the construction sector. ${ }^{6}$

\section{Box 1: Covid-19 and migrant construction workers: case studies}

Low skilled labour migrants and other migrants and ethnic minority groups have many risk factors and vulnerabilities for covid-19: these include living in overcrowded accommodation, occupational risk, precarious working environments with few safety nets, and, importantly, barriers to, and exclusion from, health systems. Data from Singapore, for example, home to about 300000 low skilled mostly Bangladeshi and Indian labour migrants largely working in construction and manufacturing sectors, found that $96 \%$ of all cases of covid-19 were in migrants living in dormitories. ${ }^{22}$

Similarly in Saudi Arabia, Ministry of Health data show that $75 \%$ of all people who had tested positive for covid-19 were migrants (up to 7 May 2020). ${ }^{23}$ A study of temporal and spatiotemporal dynamics of the covid-19 pandemic in Kuwait found that densely populated areas and poor living conditions of migrant workers related to the most important spreading and clustering events within their communities. ${ }^{24}$ Migrants were often subject to enforced lockdowns in these circumstances for lengthy periods and unable to return home.

Restrictions and safety measures in the workplace to combat covid-19 have not been adopted equally across sectors. Workers engaged in building projects for the stadiums for the FIFA World Cup in Qatar were considered critical, and the sector was exempted from lockdown and

movement restrictions throughout the pandemic. ${ }^{25}$ Although employers were meant to ensure that sanitisation and social distancing practices were maintained on construction sites, workforce reduction measures were seldom imposed so as not to jeopardise tight deadlines for project delivery.

Qatar was not alone in adopting these measures. Many countries exempted construction workers from a full lockdown, considering their labour to be essential for ensuring continued critical infrastructure viability. Migrant construction workers may have been overexposed to SARS-CoV-2, a finding reported for other migrant populations elsewhere. ${ }^{21}$

\section{Investing in health and social conditions}

The health of migrant workers and its governance are politicised, and concerns for the health of workers often remain at the margins of policy making. ${ }^{2324}$ This is a mistake because investment in the health of migrant construction workers aligns with the host country's commitments to promote health, including ensuring universal health coverage, and can also result in gains to productivity and public health.

Workers' health can be promoted through inclusive health systems, occupational risk mitigation, and fair working environments. These policy responses relate to the vision of the United Nations' sustainable development goals to "leave no one behind" and the UN Global Compact for Safe, Orderly and Regular Migration. 2529 The interests of labour migrants-and the families they leave behind-are enshrined in international human rights. ${ }^{30}{ }^{31}$ They underline states' obligations to fulfil the right to health and determinants of health for migrant workers as for nationals, including regulations on overtime, working hours safety, and health. ${ }^{31}$

Beyond the normative and legal requirements, investment in labour migrants' health make sense for public health and economic reasons. Covid-19 has been a wake-up call that inclusive approaches to public health are crucial, and tackling the health needs of international migrant workers is an urgent public health priority. ${ }^{32}$ Labour migrants may have faced a higher risk of SARS-CoV-2 infection 3334 and cannot be left out of responses to covid-19 or vaccination programmes. 35
Prevention of risks related to working and living conditions, such as overcrowding, is necessary to protect individual migrants and to promote public health. In Singapore, foreign migrant workers are being considered a priority population for covid-19 vaccination owing to the higher risk of infection associated with communal living and working conditions, and other unique risk factors and vulnerabilities for covid-19. ${ }^{2136}$ The World Health Organization has identified low income migrant workers and irregular migrants as priority groups for covid-19 vaccination. ${ }^{37}$ The UN International Organisation for Migration has called on member states to include all migrants in national covid-19 vaccine distribution plans..$^{38}$ Emerging data from some high income countries show low uptake of the covid-19 vaccine in migrants specifically, ${ }^{22}$ suggesting tailored and targeted strategies may be needed to ensure access to the vaccines, reduce barriers to health and vaccination systems, and tackle issues such as vaccine hesitancy and misinformation. 39

Approaches to migrant construction workers' health should not be limited to infectious disease control. Mental, physical, occupational, and other health issues should be central considerations in policy making. ${ }^{9}$ Home countries often have health programmes targeting migrant workers, ${ }^{8}$ including screening for infectious diseases. Testing positive for HIV or tuberculosis, for example, can mean visa applications are denied. Thus, the health status of migrant workers becomes the defining feature of access to working opportunities. Intense medical vetting of low skilled labour migrants may have only a limited effect on public health but could contribute to reluctance among migrants to seek medical attention or alert employers about ill health. ${ }^{40}$

Countries and industries reliant on labour migration depend on the health and wellbeing of migrant construction workers. Economic analysis that considers the wide ranging costs and benefits for migrants, countries, and industries is needed. Investment in prevention, through safe working and living conditions and inclusion of migrant workers in health plans, could help avoid long term illness, costly rehabilitation, long term damage, and loss of working skills.

Ill health and occupational injuries affect not only migrants but also their families and health systems in home countries. ${ }^{14}$ Investing in the health of migrant construction workers can directly benefit their health and productivity, and indirectly the success of countries and industries dependent on this population. Following simple, evidence based guidance at a construction site for the Qatar 2022 FIFA World Cup had substantial benefits for health and productivity..$^{4142}$ As illustrated by the covid-19 pandemic, the costs of poorly managed outbreaks, lockdowns, and economic stimulus packages go far beyond the costs of effective public health responses. 43

\section{Open policy windows}

In the years of preparation, big sporting events attract attention from industries, media, tourists, and others. Host countries want an enduring legacy for events such as the Olympic Games or FIFA World Cup. Economic analysis shows that events such as the Olympic Games increase exports by over $20 \%$ in host countries, attributable to the signal a country sends when bidding to host the games. 44

Just as big sporting events rely on multisectoral and multistakeholder action to be successful, these events present unique opportunities to bring changes for migrant construction workers and their health. The international spotlight before, during, and after these events may also fall on migrants' living and working 
conditions, including human rights violations. ${ }^{3}$ This scrutiny may help hold stakeholders to account, which may spur policy reforms.

The 2014 FIFA World Cup in Brazil provided an opportunity for coordinated action between national and international union organisations to improve working conditions and collective bargaining. ${ }^{45}$ Close coordination between Qatar and the International Labour Organization to uphold migrant workers' rights began in 2018, and in 2020 resulted in substantial labour reforms, including establishing workers' right to change jobs, the creation of a non-discriminatory minimum wage, 4647 and strengthened legislation related to heat exposure..$^{48}$

FIFA and the International Olympic Committee have been repeatedly questioned about exploitation of migrant workers by civil society and researchers. ${ }^{49}$ Perceptions about who is responsible for ensuring the health and rights of migrant construction workers may change in the context of big sporting events. These include how governments, international sports bodies, and industry are perceived by others and themselves, and how they take action. In the international spotlight of big sporting events, governments may see policy options-for example, Qatar's labour reforms and occupational safety and health policies ${ }^{46} 5^{0}$-as necessary. Big sporting events could set the agenda and influence the development of new policies, opening "windows of opportunity" to advance the health of migrant construction workers. ${ }^{51}$

\section{Responses and responsibilities}

The health of migrant construction workers is shaped by public and private policy responses in the migration process: in their place of origin, during transit, at their destination, and after return. ${ }^{911}$ Table 1 highlights recommendations and assigns responsibilities for concerned actors to advance health systems, tackle social determinants of health, and promote accountability for the health of migrant construction workers. ${ }^{11}$ 
Table 1| Recommendations to improve health of migrant workers

\begin{tabular}{|c|c|c|c|c|c|c|c|}
\hline & Host countries & $\begin{array}{l}\text { Industries and sports } \\
\text { organisations }\end{array}$ & $\begin{array}{l}\text { Countries sending } \\
\text { migrants }\end{array}$ & Researchers & Media & Civil society & $\begin{array}{l}\text { International } \\
\text { organisations }\end{array}$ \\
\hline $\begin{array}{l}\text { Health system: } \\
\text { prevention, healthcare, } \\
\text { public health, } \\
\text { occupational health }\end{array}$ & $\begin{array}{l}\text { Ensure universal } \\
\text { health coverage, } \\
\text { including financial risk } \\
\text { protection and } \\
\text { inclusive public health } \\
\text { policies for all migrant } \\
\text { construction workers. } \\
\text { Reduce or mitigate } \\
\text { specific health risks } \\
\text { related to big sporting } \\
\text { events }\end{array}$ & $\begin{array}{l}\text { Ensure access to } \\
\text { affordable healthcare } \\
\text { for employees, } \\
\text { including prevention, } \\
\text { healthcare, screening, } \\
\text { vaccination, etc. } \\
\text { Provisions must be } \\
\text { made to ensure paid } \\
\text { sick leave. } \\
\text { Effective data } \\
\text { collection to monitor } \\
\text { injuries, deaths, } \\
\text { mental health, } \\
\text { infections, vaccination, } \\
\text { and other health } \\
\text { needs of migrant } \\
\text { construction workers } \\
\text { and returnees. } \\
\text { Financial support and } \\
\text { compensation } \\
\text { mechanisms for } \\
\text { returnees if suffering } \\
\text { from occupational ill } \\
\text { health or injury. } \\
\text { Mitigate specific health } \\
\text { risks related to big } \\
\text { sporting events }\end{array}$ & $\begin{array}{l}\text { Consider particular } \\
\text { health risks of migrant } \\
\text { construction workers } \\
\text { (pre-departure and on } \\
\text { return). } \\
\text { Ensure ethical } \\
\text { pre-departure } \\
\text { screening and } \\
\text { follow-up (including } \\
\text { effective treatment). } \\
\text { Healthcare support for } \\
\text { returning migrant } \\
\text { workers with injury or } \\
\text { illness }\end{array}$ & $\begin{array}{l}\text { Analyse and demand } \\
\text { use of existing health } \\
\text { data. } \\
\text { Analyse disaggregated } \\
\text { data (eg by health } \\
\text { issues, type of migrant } \\
\text { group, sex). } \\
\text { Document practices }\end{array}$ & $\begin{array}{l}\text { Report on the heath of } \\
\text { migrant construction } \\
\text { workers before, } \\
\text { during, and after big } \\
\text { sporting events. } \\
\text { Document changes in } \\
\text { policy and practice }\end{array}$ & $\begin{array}{l}\text { Advocate the right to } \\
\text { health of migrant } \\
\text { construction workers, } \\
\text { through reporting and } \\
\text { advocacy }\end{array}$ & $\begin{array}{l}\text { Promote } \\
\text { mainstreaming of } \\
\text { migrant construction } \\
\text { workers in health } \\
\text { systems and public } \\
\text { health policies, } \\
\text { nationally and globally. } \\
\text { Collaborate with } \\
\text { existing institutions to } \\
\text { promote sustainable } \\
\text { changes }\end{array}$ \\
\hline $\begin{array}{l}\text { Social determinants of } \\
\text { health: working, living, } \\
\text { and social conditions }\end{array}$ & $\begin{array}{l}\text { Safe working } \\
\text { conditions in public } \\
\text { sector and across } \\
\text { departments and } \\
\text { policies } \\
\text { Ensure and enforce } \\
\text { labour standards (ILO) } \\
\text { in the public sector } \\
\text { and private industries. } \\
\text { Ethical recruitment } \\
\text { (expectations and } \\
\text { rules for labour } \\
\text { brokers and } \\
\text { recruitment agencies) }\end{array}$ & $\begin{array}{l}\text { International sports } \\
\text { organisations to } \\
\text { demand and ensure } \\
\text { host countries meet } \\
\text { International Labour } \\
\text { Organization } \\
\text { (ILO)/other minimum } \\
\text { standards, including in } \\
\text { bidding processes to } \\
\text { host big sporting } \\
\text { events. } \\
\text { Ensure safe working } \\
\text { conditions in } \\
\text { industries to prevent } \\
\text { occupational risks and } \\
\text { promote health. } \\
\text { Improve social and } \\
\text { living conditions in } \\
\text { labour } \\
\text { compounds-eg } \\
\text { tackling overcrowding, } \\
\text { access to sanitation } \\
\text { facilities. } \\
\text { Ethical recruitment: } \\
\text { demonstrate best } \\
\text { practice and adhere to } \\
\text { rules (including big } \\
\text { sporting organisations, } \\
\text { recruitment agencies, } \\
\text { etc) }\end{array}$ & $\begin{array}{l}\text { Inform migrants about } \\
\text { working, living, and } \\
\text { social conditions in the } \\
\text { construction sector in } \\
\text { other countries. } \\
\text { Ensure and enforce } \\
\text { ethical recruitment } \\
\text { processes } \\
\text { pre-departure }\end{array}$ & $\begin{array}{l}\text { Analyse and connect } \\
\text { data linking health and } \\
\text { social, occupational, } \\
\text { and structural } \\
\text { determinants of health }\end{array}$ & $\begin{array}{l}\text { Report on the health } \\
\text { and working, living } \\
\text { and social conditions. } \\
\text { Document changes in } \\
\text { policy and practice }\end{array}$ & $\begin{array}{l}\text { Advocate for fair } \\
\text { working, living, and } \\
\text { social conditions. } \\
\text { Report on unfair } \\
\text { conditions }\end{array}$ & $\begin{array}{l}\text { Promote } \\
\text { mainstreaming of the } \\
\text { needs and rights of } \\
\text { migrant construction } \\
\text { workers across } \\
\text { sectors and levels. } \\
\text { Collaborate with } \\
\text { existing institutions to } \\
\text { promote sustainable } \\
\text { legal, policy, and } \\
\text { implementation } \\
\text { changes }\end{array}$ \\
\hline Accountability & $\begin{array}{l}\text { Advance legislation to } \\
\text { ensure the right to } \\
\text { health. } \\
\text { Hold health systems, } \\
\text { other sectors and } \\
\text { industries to account } \\
\text { in promoting the } \\
\text { health of workers }\end{array}$ & $\begin{array}{l}\text { Demand changes to } \\
\text { public policies and } \\
\text { adhere to policies } \\
\text { (when relevant). } \\
\text { Influence norms and } \\
\text { standards by } \\
\text { supporting best } \\
\text { practices. } \\
\text { Hold host countries } \\
\text { accountable to protect } \\
\text { the health of migrant } \\
\text { construction workers }\end{array}$ & $\begin{array}{l}\text { Demand changes to } \\
\text { public policy and } \\
\text { adhere to policies in } \\
\text { dialogue with host } \\
\text { country and industries. } \\
\text { Support and empower } \\
\text { migrants to uphold } \\
\text { their rights }\end{array}$ & $\begin{array}{l}\text { Hold host countries } \\
\text { and industries } \\
\text { responsible }\end{array}$ & $\begin{array}{l}\text { Report to hold } \\
\text { countries, industries, } \\
\text { and other actors } \\
\text { responsible. } \\
\text { Document best } \\
\text { practices and/or } \\
\text { breaches of } \\
\text { international law and } \\
\text { national standards }\end{array}$ & $\begin{array}{l}\text { Demand action by all } \\
\text { stakeholders, in } \\
\text { particular in host } \\
\text { countries and } \\
\text { industries }\end{array}$ & $\begin{array}{l}\text { Support countries and } \\
\text { industries in their } \\
\text { agendas to ensure the } \\
\text { health of migrant } \\
\text { construction workers. } \\
\text { Demand changes in } \\
\text { unacceptable policies } \\
\text { or practices }\end{array}$ \\
\hline
\end{tabular}


Host countries, international sports industries (including FIFA and the International Olympic Committee), and other organisations are the most influential stakeholders that can guarantee safe and affordable essential services and public health programmes ensuring safe working, social, and living environments for migrant workers. They should be held accountable by countries taking parts in such events, countries sending migrant workers, civil society, researchers, other businesses, human rights organisations, and others.

Stakeholders benefitting from big sporting events should uphold and adhere to minimum international and national standards in the workplace and in accommodation in preparations for, during, and after such events. Although countries are obliged to do so based on human rights principles, ${ }^{30}{ }^{11}$ they are far from realising these commitments for labour migrants.

The International Labour Organization's labour standards apply to all workers, including labour migrants, with minimum standards on employment, safety, working conditions, social security, and with regards to equality of treatment. ${ }^{13}{ }^{52}$ Yet international labour standards are guidelines and not obligations unless they are enacted in national law. A key step to enable sustainable improvements in working conditions and health rights 47 are changes in national legislation, such as for the labour reforms in Qatar. ${ }^{34648}$ These must be supported by financial resources to ensure policy implementation and compliance as well as practices in industries benefitting from big sporting events. Host countries must ensure universal coverage in health and public health systems that cater for the needs of migrant workers.

Private sector and international organisations concerned in the construction and accommodation sectors have key roles as implementing partners. They can help shift norms and practices to safeguard working conditions and prevent occupational risks. ${ }^{3}$ The lack of visibility of international sports organisations in public debates on fair working conditions and the health of the people constructing world class sporting arenas is unacceptable. These institutions have a key responsibility in demanding and ensuring that host countries meet International Labour Organization and other minimum standards, and such expectations should be incorporated in bidding processes to host big sporting events. FIFA's engagement in health is long overdue. ${ }^{53}$ In qualification matches for the Qatar World Cup 2022 several football teams have called for the protection of human rights of migrant workers. 54

When multiple organisations demand changes, public perceptions may alter, which can influence policy processes and agenda setting. ${ }^{51}$ Migrants' home countries, often low and middle income countries, must consider migrant construction workers a key population facing particular risks before their departure and on return.

Researchers can have an important role in demanding transparency, compliance with international labour standards, and sharing of data. As elaborated in our companion paper, ${ }^{6}$ researchers must strive to engage in policy dialogue with labour migrants themselves. Their experiences should serve as an empirical basis for developing policies, and migrants should be included in determining what essential improvements are needed.

Just as host countries may use big sporting events to showcase the country and hoped for legacies, civil society and journalists should use the international spotlight to scrutinise the health and social conditions of migrant construction workers and compliance with international labour standards. ${ }^{47}$ By holding governments, international sporting organisations, and private sector stakeholders to account, these actors can facilitate overdue policy changes.
International non-governmental organisations, such as the International Labour Organization, International Organization for Migration, and other UN organisations, should make use of the international momentum that big sporting events bring. ${ }^{49}$ These organisations should have crucial roles in widely publicising the needs of migrant workers in health systems and other sectors, and in facilitating sustainable collaboration between different institutions.

The recommendations on responses and responsibilities are based on minimum standards from the International Labour Organization and proposals on inclusive approaches to migration and health. 94752 In reality, migrant construction workers are temporary populations in host countries and far removed from those in power and decision makers. For international events such as the Olympic Games and FIFA World Cup, it is crucial that multiple stakeholders tackle the accountability vacuum by demanding action and question when minimum standards are not met, alongside calling for greater emphasis on research and service delivery to improve health and strengthen data collection. ${ }^{6}$

\section{Promoting healthy migration}

Big sporting events present windows of opportunity for multisectoral and multistakeholder action to improve the health of migrant construction workers. The increased vulnerability to covid-19 infection in low skilled migrant workers could be an additional factor that leads to overdue policy changes to tackle health and underlying structural risks.

Policy responses that improve these people's health and social situation would also generate public health and economic benefits and ensure that countries meet international labour standards and commitments to human rights and the sustainable development goals. These gains hold relevance to the diverse range of low skilled labour migrants who will continue to search of work and opportunities abroad.

Investment in the health of migrant construction workers is the responsibility and in the interests of the construction sector, particularly for big sporting events. Unacceptable working, living, and health conditions of migrant construction workers highlight the need for leadership from all stakeholders. In the global economy, all actors, particularly host countries, international sporting organisations, and industry, must be held to account to ensure that the health of migrant construction workers is an integrated outcome of all work.

\section{Key recommendations}

- Multimillion dollar sporting events in high income countries, such as the Summer Olympic Games in Japan and FIFA World Cup in Qatar, shine a light on unacceptable working, living, and health conditions of many migrant construction workers.

- The international focus of big sporting events should be used to hold all actors, particularly host countries, international sporting organisations, and industries, responsible to take action to protect the health of labour migrants and ensure their access to health and vaccination systems, alongside catalysing a renewed focus on data collection, research, and evidence based policy making in this neglected area.

- Governments and industries benefitting from big sporting events should as a minimum uphold and adhere to international and national standards in the workplace and in living quarters in preparations for, during, and after such events.

- Sustainable improvements in working conditions and health rights must be guaranteed through changes in national legislation that 
provide universal health coverage and tackle wider social determinants of health.

- Industries and countries taking part in international events, countries sending migrants, civil society, researchers, human rights organisations, and others must hold stakeholders to account to advance the health of labour migrants.

Competing interests: We have read and understood BMJ policy on declaration of interests and have no interests to declare.

Provenance and peer review: Commissioned; externally peer reviewed.

This article is part of a series commissioned by The BMJ for the World Innovation Summit for Health (WISH). The BMJ peer reviewed, edited, and made the decisions to publish. The series, including open access fees, is funded by WISH.

SH is funded by the NIHR (advanced fellowship NIHR300072) and the Academy of Medical Sciences (SBF005\1111) and acknowledges input from the ESCMID Study Group for Infections in Travellers and Migrants. ADF is supported by the European Union's Horizon 2020 research and innovation programme (project HEAT-SHIELD; grant agreement no 668786).

1 International Labour Organization. ILO global estimates on international migrant workers. International Labour Organization, 2018.

2 World Bank. COVID-19: Remittance flows to shrink 14\% by 2021. 2021. https://www.worldbank.org/en/news/press-release/2020/10/29/covid-19-remittance-flows-to-shrink-14-by-2021.

3 Batho J. Keeping the focus on protecting migrant worker rights-new tool for hotels in Qatar. 2020. https://www.hrb.org/focus-areas/migrant-workers/commentary-fair-recruitment-employment-qatar-hotels.

4 Meza Talavera A, Al-Ghamdi SG, Koç M. Sustainability in mega-events: beyond Qatar 2022. Sustainability 2019;11:6407. doi: 10.3390/su11226407

5 Memish ZA, Steffen R, White P, etal. Mass gatherings medicine: public health issues arising from mass gathering religious and sporting events. Lancet 2019;393:2073-84 doi: 10.1016/S0140-6736(19)30501-X pmid: 31106753

6 Flouris AD, Babar Z, loannou LG, etal. Improving the evidence on health inequities in migrant construction workers preparing for big sporting events: health of low-skilled labour migrants involved in construction for mega sporting events. BMJ2021;374:n1615. doi: 10.1136/bmj.n1615

7 Aldridge RW, Nellums LB, Bartlett S, etal. Global patterns of mortality in international migrants: a systematic review and meta-analysis. Lancet 2018;392:2553-66.

doi: 10.1016/S0140-6736(18)32781-8 pmid: 30528484

8 IOM. Health of labour migrants 2021. https://www.iom.int/health-labour-migrants.

9 Abubakar I, Aldridge RW, Devakumar D, etalUCL-Lancet Commission on Migration and Health. The UCL-Lancet Commission on Migration and Health: the health of a world on the move. Lancet 2018;392:2606-54. doi: 10.1016/S0140-6736(18)32114-7 pmid: 30528486

10 Castañeda H, Holmes SM, Madrigal DS, Young ME, Beyeler N, Quesada J. Immigration as a social determinant of health. Annu Rev Public Health 2015;36:375-92.

doi: 10.1146/annurev-publhealth-032013-182419 pmid: 25494053

11 IOM. Social determinants of migrant health. 2021. https://www.iom.int/social-determinants-migrant-health.

12 Hargreaves S, Rustage K, Nellums LB, etal. Occupational health outcomes among international migrant workers: a systematic review and meta-analysis. Lancet Glob Health 2019;7:e872-82. doi: 10.1016/S2214-109X(19)30204-9 pmid: 31122905

13 Devkota HR, Bhandari B, Adhikary P. Perceived mental health, wellbeing and associated factors among Nepali male migrant and non-migrant workers: a qualitative study. J Migr Health 2021:3:100013. doi: 10.1016/j.jmh.2020.100013

14 Fellmeth G, Rose-Clarke K, Zhao C, etal. Health impacts of parental migration on left-behind children and adolescents: a systematic review and meta-analysis. Lancet 2018;392:2567-82 doi: 10.1016/S0140-6736(18)32558-3 pmid: 30528471

15 Sun Y, Fang D, Wang S, etal. Safety risk identification and assessment for Beijing Olympic venues construction. J Manage Eng 2008;24:40-7.doi: 10.1061/(ASCE)0742-597X(2008)24:1(40)

16 Senouci A, Al-Abbadi I, Eldin N. Safety improvement on building construction sites in Qatar. Procedia Eng 2015;123:504-9.doi: 10.1016/.jproeng.2015.10.102

17 GamaGato L, Salazar NB. Constructing a city, building a life: Brazilian construction workers continuous mobility as a permanent life strategy. Mobilities 2018;13:733-45.doi: 10.1080/17450101.2018.1466504

18 Theodoropoulou I. Blue-collar workplace communicative practices: a case study in construction sites in Qatar. Lang Policy 2020;19:363-87. doi: 10.1007/s10993-019-09518-z

19 Mohammad R, Sidaway JD. Shards and stages: migrant lives, power, and space viewed from Doha, Qatar. Ann Am Assoc Geogr 2016;106:1397-417. doi: 10.1080/24694452.2016.1209402

20 Patel JA, Nielsen FBH, Badiani AA, etal. Poverty, inequality and COVID-19: the forgotten vulnerable. Public Health 2020;183:110-1. doi: 10.1016/j.puhe.2020.05.006 pmid: 32502699

21 Hayward SE, Deal A, Cheng C, etalESCMID Study Group for Infections in Travellers and Migrants (ESGITM). Clinical outcomes and risk factors for COVID-19 among migrant populations in high-income countries: Aa systematic review. J Migr Health 2021;3:100041. doi: 10.1016/j.jmh.2021.100041 pmid: 33903857
22 European Centre for Disease Prevention and Control. Reducing COVID-19 transmission and strengthening vaccine uptake among migrant populations in the EU/EEA - 3 June 2021. ECDC, 2021.

23 Wickramage K, Annunziata G. Advancing health in migration governance, and migration in health governance. Lancet2018;392:2528-30. doi: 10.1016/S0140-6736(18)32855-1 pmid: 30528473

24 Wickramage K, Simpson PJ, Abbasi K. Improving the health of migrants. BMJ 2019;366:15324. doi: 10.1136/bmj.l5324 pmid: 31527076

25 Cousins S. Migrant workers can't afford a lockdown. Foreign Policy 2020 Apr 8. https://foreignpolicy.com/2020/04/08/qatar-south-asian-migrant-workers-cant-afford-coronavirus-lockdownworld-cup-2022

26 Al Kuwari HM, Abdul Rahim HF, Abu-Raddad LJ, etal. Epidemiological investigation of the first 5685 cases of SARS-CoV-2 infection in Qatar, 28 February-18 April 2020.BMJ Open 2020;10:e040428. doi: 10.1136/bmjopen-2020-040428 pmid: 33033033

27 Ali MA, Al-Khani AM, Sidahmed LA. Migrant health in Saudi Arabia during the COVID-19 pandemic East Mediterr Health J2020;26:879-80. doi: 10.26719/emhj.20.094 pmid: 32896880

28 Kuhlmann E, Falkenbach M, Klasa K, etal. Migrant carers in Europe in times of COVID-19: a call to action for European health workforce governance and a public health approach. Eur J Public Health 2020;30(suppl 4):iv22-7. doi: 10.1093/eurpub/ckaa126

29 United Nations. Transforming our world: the 2030 agenda for sustainable development. UN, 2015.

30 United Nations General Assembly. International covenant on economic, social and cultural rights. UN, 1966.

31 United Nations General Assembly. International convention on the protection of the rights of al migrant workers and members of their families. UN, 1990.

32 Liem A, Wang C, Wariyanti Y, Latkin CA, Hall BJ. The neglected health of international migrant workers in the COVID-19 epidemic. Lancet Psychiatr 2020;7:e20. doi: 10.1016/S2215-0366(20)30076-6 pmid: 32085842

33 Alkhamis MA, Al Youha S, Khajah MM, etal. Spatiotemporal dynamics of the COVID-19 pandemic in the State of Kuwait. Int I Infect Dis 2020;98:153-60. doi: 10.1016/j.jiji.2020.06.078 pmid: 32619761

34 Chew MH, Koh FH, Wu JT, etal. Clinical assessment of COVID-19 outbreak among migrant workers residing in a large dormitory in Singapore. J Hosp Infect 2020;106:202-3. doi: 10.1016/j.jhin.2020.05.034 pmid: 32492454

35 Mukumbang FC. Are asylum seekers, refugees and foreign migrants considered in the COVID-19 vaccine discourse. BMJ Glob Health 2020;5:e004085. doi: 10.1136/bmigh-2020-004085 pmid: 33177039

36 Zhang L. Migrant workers in higher-risk dorms to be vaccinated first. The Straits Times 2021. https://www.straitstimes.com/singapore/politics/migrant-workers-in-higher-risk-dorms-to-bevaccinated-first-tan-see-leng.

37 World Health Organization. WHO SAGE values framework for the allocation and prioritization of COVID-19 vaccination, 14 September 2020. World Health Organization, 2020

38 IOM, UN Migration. Ensuring migrants' equitable access to COVID-19 vaccines. 2021 https://www.iom.int/ensuring-migrants-equitable-access-covid-19-vaccines.

39 Crawshaw AF, Deal A, Rustage K, etal. What must be done to tackle vaccine hesitancy and barriers to COVID-19 vaccination in migrants?] Travel Med 2021;28:taab048. doi: 10.1093/jtm/taab048 pmid: 33772312

40 Loganathan T, Rui D, Pocock NS. Healthcare for migrant workers in destination countries: a comparative qualitative study of China and Malaysia. BMJ Open 2020;10:e039800. doi: 10.1136/bmjopen-2020-039800 pmid: 33268413

41 Ioannou LG, Mantzios K, Tsoutsoubi L, etal. Occupational heat stress: multi-country observations and interventions. Int J Environ Res Public Health 2021;18:6303. doi: 10.3390/ijerph18126303

42 Flouris AD, loannou LG, Dinas CD, etal. Assessment of occupational heat strain and mitigation strategies in Qatar-key findings. International Labour Organization, 2019.

43 Çakmaklı C, Demiralp S, Kalemli-Özcan S, etal. The economic case for global vaccinations: an epidemiological model with international production networks. Nation Bureau of Economic Research, 2021.doi: 10.3386/w28395

44 Rose AK, Spiegel MM. The Olympic effect. Econ J (Lond) 2011;121:652-77. doi: 10.1111/.1468-0297.2010.02407.x

45 Rombaldi M. The 2014 World Cup and the construction workers: global strategies, local mobilizations. Lat Am Perspect 2019;46:53-65. doi: 10.1177/0094582X19842837

46 International Labour Organization. Changes in the labour market in Qatar: dismantling the kafala system and introducing a minimum wage mark new era for Qatar labour market 2020. https://www.lo.org/beirut/projects/qatar-office/WCMS_754391/lang--en/index.htm.

47 International Labour Organization. Monitoring compliance with international labour standards: the key role of the ILO Committee of Experts on the Application of Conventions and Recommendations. ILO, 2019.

48 International Labour Organization. New legislation in Qatar provides greater protection to workers from heat stress. 2021. https://www.ilo.org/global/about-the-ilo/newsroom/news/WCMS_794475/lang--en/index.htm.

49 Le D. Leveraging the ILO for human rights and workers' rights in international sporting events. Hastings Communications and Entertainment Law Journal 2020;171. https://repository.uchastings.edu/hastings_comm_ent_law_journal/vol42/iss2/4/.

50 Ministry of Administrative Development, Labour and Social Affairs, Ministry of Public Health. Occupational safety and health policy in the state of Qatar. 2020. 
51 Kingdon JW. Agendas, alternatives, and public policies. Little Brown, 1984.

52 International Labour Organization. International labour standards on labour migration. 2021.

https://www.ilo.org/global/topics/labour-migration/standards/lang--en/index.htm.

53 World Health Organization. FIFA and WHO \#ACTogether to tackle COVID-19. 2021

https://www.who.int/news/item/01-02-2021-fifa-and-who-actogether-to-tackle-covid-19.

54 Germany players wear T-shirts in protest against Qatar's human rights record BBC. BBC News 2021. https://www.bbc.com/sport/football/56534835.

This is an Open Access article distributed in accordance with the Creative Commons Attribution Non Commercial (CC BY-NC 4.0) license, which permits others to distribute, remix, adapt, build upon this work non-commercially, and license their derivative works on different terms, provided the original work is properly cited and the use is non-commercial. See: http://creativecommons.org/licenses/by$\mathrm{nc} / 4.0 \%$. 